\title{
NORDIC COUNTRIES IN FINNISH PERSPECTIVE
}

The year 2020 will be remembered, among other things, for Brexit, the case of Alexei Navalnyi, the events in Belarus and the chaotic situation in the USA with its dramatic presidential elections. As for Finland, 2020 witnessed heated debates between the red-green government - led by Sanna Marin, the country's first female social-democratic prime minister - and the rightist opposition.

First and foremost, the world will remember 2020 as a year of grief as all nations were faced with the coronavirus pandemic. Countries have taken various measures to contain the virus, which have had a small effect also on this journal. One of the articles could not be finished because archives were closed in the spring. The Nordic labour history congress planned to be held in Copenhagen this November had to be cancelled. With this year's international theme in mind, our journal was supposed to be introduced at the congress and five of the articles are written in English. Nordic readers can acquaint themselves with the "Nordic topics" of our international theme issue in a "neutral" language.

Our theme this year is "Nordic countries in Finnish perspective". For historical and geographic reasons the relationship between the Finnish and Swedish labour movement has been very close, even though, delightfully, in recent decades, the Finnish labour movement's relationships with the labour movements in Norway, Denmark and Iceland have also intensified. The theme articles of this volume show how the ties to Sweden can manifest themselves in the various research projects of Finnish scholars. Articles by Dr. Sami Outinen and Dr. Ilkka Kärrylä explore the ideological development of the Finnish and Swedish Social Democratic Parties and the discussions among Finnish social-democrats and the trade unions in the 1970s and 1980s on the Swedish wage-earner fund model. Dr. Mikko-Olavi Seppälä examines the ways in which theatre plays of the 1970 s reflect the conceptions that Finnish immigrants in Sweden had on the EEC.

Exactly 100 years ago, the labour movement further left of the Social Democratic Party began its domestic activities here in Finland. Thus, Dr. Tauno Saarela explores the history of the Finnish Socialist Workers' Party which was founded in 1920. Dr. Matias Kaihovirta discusses the influences of Karl Harald Wiik on how the national question was viewed in the Finnish Social Democratic Party during the first half of the 20th century. Maija Absetz writes about the Unemployment Security Act which was passed in 1984, and Pentti Peltoniemi discusses the labour market status of freelance journalists in the past. Again, our articles cover a wide range of topics, as do labour studies in general, too.

The Discussion section of this volume also looks towards the other Nordic countries. The director of the Danish Labour Museum Søren Bak-Jensen and the director of the Norwegian Labour Movement Archive and Library, Dr. Ole Martin Rønning inform us about the current state of their institutions. As usual, this volume introduces some of the new Master's theses in the field of labour movement studies and offers a broad selection of reviews on new books in labour movement studies. Finally, the Finnish labour heritage organisations share their news.

I hope you enjoy the volume and I wish everyone a better year 2021 .

\section{Erkki Vasara}

Editor-in-chief

erkki.vasara@helsinki.fi 